\title{
Performance Evaluation of Cluster Front Line Demonstration Programme on Sesame (Sesamum indicum L.) in Samastipur District, Bihar, India
}

\author{
Shailesh Kumar, R. K. Tiwari*, Sanjay Kumar, Ranjan Kumar, Sanchita Ghosh, \\ Bharati Upadhaya, Nisha Rani and Vidyapati Choudhary
}
Krishi Vigyan Kendra, Birauli, Samastipur-848113, Dr. Rajendra Prasad Central Agricultural University, Pusa, Samastipur, Bihar, India

*Corresponding author

\begin{abstract}
A B S T R A C T
The Cluster Front Line Demonstration (CFLD) programme on sesame was carried out in operational area of Krishi Vigyan Kendra, Samastipur during 2018-19. The fields were selected from different villages/clusters (each of 0.2-0.4 ha) of the district. The variety 'Krishna' was sown at all the located fields. Fertilizer, compost application and plant protection measures were provided as per recommended package of practices. From the CFLD prgoramme it was found that the seed yield of sesame was $5.0 \mathrm{q} / \mathrm{ha}$ in demonstration field as compared to yield obtained from farmers field $(3.20 \mathrm{q} / \mathrm{ha})$. The technology gap was found to be 1.5 $\mathrm{q} / \mathrm{ha}$. The $1.8 \mathrm{q} / \mathrm{ha}$ extension gap was found in that season. The technology index was $23.07 \%$. Higher gross returns (Rs 25000/ha), net return (Rs. 15530/ha and benefit-cost ratio of 2.63 was found in demonstrated field as compared to benefitcost ratio of 1.63 in case of local check. The significant yield is attributed due to introduction of new variety in cluster mode which facilitated better crop management.
\end{abstract}

Keywords

Sesame, CFLD, yield, B:C ratio, technology index

Article Info

Accepted:

05 April 2020

Available Online:

10 May 2020

\section{Introduction}

Sesame (Sesame indicum L.) also known as til is called as "queen of oilseeds crops" by virtue of its excellent oil quality. India ranks first in the world with 19.50 lakh ha sown area and 8.50 lakh tones production. It is a versatile crop and the average yield of sesame (436 kg/ha) in India is low as compared with other country in the world $(535 \mathrm{~kg} / \mathrm{ha})$
(Anonymous, 2015). It is having the highest oil content (46-64\%) and rich in beneficial properties due to their high content of proteins, minerals and vitamins.

In Ayurveda, sesame oil is used as medicine and also used in cooking many dishes. Sesame adds beneficial residue within the whole soil profile, resulting in improved tillage and top soil properties and in a crop 
rotation reduces nematodes in the soil. As a drought and heat tolerant crop, it has the ability to retain a relatively high level of hydration under conditions of soil/atmospheric water stress. Under the changing climate scenario due to low monsoon precipitation it has becomes necessary to develop mechanism for reaching out and demonstrating the improved technology under the Samastipur district farming conditions. In order to address these short comings, the Government of India has devised a programme to promote the pulse cultivation in cluster mode under National Food Security Mission through KVKs. The main objective of CFLD is to demonstrate production technology and its management practices on farmer's field under different farming situations. These demonstrations are carried out under the supervision of agricultural scientists and feedbacks from the different farmers have to be generated for the demonstrated technology. Keeping the importance of CFLD the KVK, Samastipur conducted demonstrations on sesame at farmer's field. The present study has been undertaken to increase the per capita availability of oilseed and popularization of new production technology amongst the farming community for sesame crop.

\section{Materials and Methods}

The study was carried out in operational area of Krishi Vigyan Kendra, Samastipur during 2018-19. The field after potato/rapeseedmustard were selected from different villages/clusters (each of 0.2-0.4 ha) of the district (Table-1). The total area of 10 ha has been allotted to KVK, Samastipur by ICARATARI, Patna (Zone-IV). The critical inputs were supplied to the farmers by the KVK and other inputs like balanced fertilizers, additional agro-chemicals, weedicides, and irrigation facility were managed by farmers himself as per the recommendation of scientists of KVK. The sesame varieties 'Krishna' were sown during last week of February to $1^{\text {st }}$ week of March in furrow at 30 $\mathrm{cm}$ row spacing and a seed rate of $5 \mathrm{~kg} / \mathrm{ha}$ at all selected the sites. Before sowing seed was treated with Bavistin (2 gm/ $\mathrm{kg}$ ). The half dose of nitrogen and full dose of phosphorous and potassium fertilizer was applied at the time of sowing and half of the nitrogenous fertilizer was top-dressed. Recommended package of practices were followed for raising the crop along with need based weed control and plant protection measures. Earlier the farmers grow this crop by their own methods through seed broadcasting etc. which is kept as local standard check. The compost is applied ones in three years by the farmers. All the farmers were trained beforehand for improved package of practices through training programme. Materials for the present study with respect to CFLD and farmers practices are given in Table-2.

In case of local check plots, existing practices being used by farmers were followed. Regular visit by the KVK scientists to demonstration field were made to guide the farmers. These visits also helped to collect feedback information from different farmers for further improvement in research and extension programme. Field days, awareness camp and group meeting were also organized at the demonstration plots to provide the opportunities for vicinity farmers to witness the benefits of these demonstrated technologies the improved technology included quality seed, seed treatment and maintenance of optimum plant population etc. Recommended weed control measure and irrigation were applied according to requirement of the crops. The crop was harvested at perfect maturity with suitable method. Desired yield data were collected through field observations. Gross return was calculated by multiplying yield into prevalent local market price of the crop obtain by the 
farmers. For estimating input cost, the sum of expenditure on land preparation, planting method, fertilizer, insecticide, fungicide, herbicide, irrigation cost, labour harvesting cost etc were calculated form each demonstration. Further net return and benefit cost ratio were calculated from these data. To estimate the technology gap, extension gap and technology index formulae devised by Samui et al., (2000) have been used. Technology gap $=$ Potential yield Demonstration yield, Extension gap = Demonstration yield - Farmers yield, Technology index = Technology gap /Potential yield x 100 .

\section{Results and Discussion}

The result of all the 29 demonstrations conducted during summer 2018-19 at farmers' field in Samastipur district has been presented in Table-3 as per the prescribed proforma provided by ICAR Agricultural Technology Application Research Institute (ATARI), Patna (Zone-IV). Farmers adopted the improved technology practices by using high yielding varieties, balance use of fertilizers and micronutrients and control of insect and disease in sesame crop and the crop was supervised by the scientists of KVK, Samastipur as per the area allotted by ATARI, Patna. The data revealed that the CFLD reflects good impact over the farming communities.

A comparison of productivity levels between local check and demonstrated varieties and practices are shown in Table-3. The seed yield of sesame was $5.0 \mathrm{q} / \mathrm{ha}$ in demonstration field as compared to seed obtained from farmers field $(3.20 \mathrm{q} / \mathrm{ha})$. Demonstration plot resulted in $36 \%$ higher seed yield from local check. Similar findings have also been observed by Sandhu and Dhaliwal (2016), Jain (2016) and Singh (2019) where results from demonstrations plots observed to be higher in summer green gram and sesame crop. The major differences were observed between demonstration package and farmers' practices are introduction of seed treatment, method and time of sowing, fertilizer doses and method of its application and plant protection measures. It is evident from the results that the yield of demonstration was found better than the local check (farmer's practice) under the similar environmental conditions. Farmers were motivated by results of demonstrations and agro-technologies applied in the cluster front line demonstration and they would adopt these all new technologies in their fields. These findings are in corroboration with the finding of Sagar and Chandra (2004), Meena et al., (2018) and Kumar et al., (2018).

The technology gap is the gap between demonstration yield and potential yield and it was $1.5 \mathrm{q} / \mathrm{ha}$. The observed technology gap as presented in Table- 3 is due to various constraints such as soil fertility, availability of low moisture content, sowing time and climatic hazards etc. Hence, to reduce the yield gap location specific recommendations for varieties and timely sowing appears to be necessary. The $1.8 \mathrm{q} / \mathrm{ha}$ extension gap was found in that season.

There is a need to decrease this wider extension gap through latest techniques. The findings are similar to the findings of Singh et al., (2018) and Meena et al., (2018). The technology index showed the feasibility of evolved technology at farmer's field. Lower technology values indicated that the feasibility of variety among the farmers is more.

The technology index was $23.07 \%$. This finding is in corroboration with the findings of Singh et al., (2019) and Meena et al., (2018). The economics of sesame production under CFLD have been presented in Table- 4 . 
Table.1 Details of farmers and cluster in different blocks of Samastipur district under CFLD programme

\begin{tabular}{|c|c|c|c|c|c|c|c|}
\hline \multirow[t]{3}{*}{ Year } & \multirow[t]{3}{*}{ No of farmers } & \multicolumn{6}{|c|}{ Name of Blocks \& Villages of Samastipur District } \\
\hline & & \multicolumn{4}{|c|}{ Kalyanpur } & Mohaddinagar & Pusa \\
\hline & & Somnaha & Phulhatta & Shivnagar & Kushiyari & Kalyanpur Basti & Morsand \\
\hline 2018-19 & 29 & $4(01)$ & $10(01)$ & $02(01)$ & $06(01)$ & $02(01)$ & $05(01)$ \\
\hline
\end{tabular}

Table.2 Comparison of cultural practices adopted by farmers and CFLD

\begin{tabular}{|c|c|c|}
\hline Cultural operations & Prevailing Practices & CFLD employing improved cultivation practices \\
\hline Use of seed & Use of local seed & Krishna \\
\hline Seed quality & Small non-graded seed & Bold graded black seed \\
\hline Seed treatments & - & Treated with Bavistin \\
\hline Method of sowing & Broadcasting & Line sowing by seed drill \\
\hline Fertilizer application & - & 40:20:20 NPK kg/ha \\
\hline Control measures & $\begin{array}{l}\text { Single spray of pesticide when severe } \\
\text { problem occurs }\end{array}$ & $\begin{array}{l}\text { Two spray of insecticides to control of insects and application of micronutrients for more } \\
\text { branches and healthy plants as well as seeds }\end{array}$ \\
\hline
\end{tabular}

Table.3 Yield, technology gap, extension gap and technology index of sesame in Samastipur

\begin{tabular}{|c|c|c|c|c|c|c|c|c|c|c|c|c|c|c|}
\hline \multirow[t]{3}{*}{ Year } & \multirow{3}{*}{$\begin{array}{l}\text { Name of } \\
\text { variety }\end{array}$} & \multirow{3}{*}{$\begin{array}{c}\text { No of } \\
\text { demon } \\
\text { stration }\end{array}$} & \multicolumn{7}{|c|}{ Yield (q/ha) } & \multirow{3}{*}{$\begin{array}{c}\text { Yield } \\
\text { increase } \\
(\%)\end{array}$} & \multirow{3}{*}{$\begin{array}{c}\% \\
\text { increase } \\
\text { over } \\
\text { check }\end{array}$} & \multirow{3}{*}{$\begin{array}{c}\text { Techno } \\
\operatorname{logy} \\
\operatorname{gap}(q / h a)\end{array}$} & \multirow{3}{*}{$\begin{array}{l}\text { Extension } \\
\text { gap (q/ha) }\end{array}$} & \multirow{3}{*}{$\begin{array}{c}\text { Techno } \\
\text { logy index } \\
(\%)\end{array}$} \\
\hline & & & Potential & & onstrat & & & Check & & & & & & \\
\hline & & & & Max. & Min. & Av. & Max. & Min. & Av. & & & & & \\
\hline 2018-19 & Krishna & 29 & 6.5 & 5.8 & 4.2 & 5 & 3.8 & 2.6 & 3.2 & 36 & 56.25 & 1.5 & 1.8 & 23.07 \\
\hline
\end{tabular}

Table 4 : Gross cost, gross return, net return and B: C ratio of sesame in Samastipur

\begin{tabular}{|c|c|c|c|c|c|c|c|c|}
\hline \multirow[t]{3}{*}{ Year } & \multicolumn{8}{|c|}{ Expenditure and return } \\
\hline & \multicolumn{4}{|c|}{ Check plots } & \multicolumn{4}{|c|}{ Demonstration plots } \\
\hline & Gross cost (Rs/ha) & $\begin{array}{c}\text { Gross Return } \\
\text { (Rs/ha) }\end{array}$ & $\begin{array}{c}\text { Net return } \\
\text { (Rs/ha) }\end{array}$ & B:C ratio & Gross cost (Rs/ha) & $\begin{array}{l}\text { Gross Return } \\
\text { (Rs/ha) }\end{array}$ & $\begin{array}{c}\text { Net return } \\
\text { (Rs/ha) }\end{array}$ & B:C ratio \\
\hline 2018-19 & 9240 & 15100 & 5860 & 1.63 & 9470 & 25000 & 15530 & 2.63 \\
\hline
\end{tabular}

Sale rate of sesame during: 2018-19: Rs. 5000/q 
Economics analysis of the yield performance revealed that CFLD recorded higher gross return (Rs. 25000/ha) and net return (Rs. $15530 /$ ha) with higher benefit-cost ratio 2.63 compared to 1.63 in case of local check. The sale rate of sesame in local market during 2018-19 was@Rs.50/kg. The higher benefit cost ratio in demonstrated plot is due to of higher yield obtained under improved technologies compared to farmers practices during the experimental year. Similar results were corroborated with Kumar et al., (2018).

It is concluded from the study that through CFLD of recommended technologies, yield of sesame can be increased to its potential yield in Samastipur district. This will substantially increase the income as well as livelihood of the farming communities. Major attention to be made on development of area specific technology module for enhancing the productivity of oilseeds in varied agroecosystem of Bihar.

\section{References}

Anonymous. 2015-16. Ministry of Agriculture, Government of India.

Jain, L. K. 2016. Impact assessment of front line demonstrations on green gram in Barmer district of Western Rajasthan. Journal of Food Legumes, 29 (3 \& 4) : 249-252.

Kumar, S., Tiwari, R.K., Ashthana, R.K. and Kumar, Shailesh. 2018. Evaluation of Different Cultivars of lentil under Cluster Front Line Demonstration Programme in Samastipur District,
Bihar. Journal of Community Mobilization and Sustainable Development. 13 (2): 271-274.

Meena, Ram Kishan, Singh, Bacchu, Meena, K.C., Meena, R.K., Singh, B. and Gurjar, Prakash. 2018. Performance of Front Line Demonstrations on Sesame in Karauli, District of Rajasthan, India. International Journal of Current Microbiology and applied Sciences. 7(3) : 1507-1511.

Sagar, R.L. and Chandra, G. 2004. Front Line Demonstration on Sesame in West Bengal. Agricultural Extension Review. pp-7-10.

Samui, S.K.; Maitra, S.; Roy, D.K.; Mondal, A.K. and Saha, D. 2000. Evaluation of front line demonstration programme on groundnut (Arachis hypogea L.). Journal of Indian Society of Coastal Agriculture Research, 18 (2) : 180-183.

Sandhu, B.S. and Dhaliwal, N.S. 2016. Evaluation of front line demonstration programme on summer moong in south Western Punjab. Journal of Food Legumes, 29 (3 \& 4) : 245-248.

Singh, K.M., Singh, L.B. and Gautam, U.S. 2019. Cluster Front Line Demonstration an Effective Tool for spreading the advance technology of Sesame among the farmers. The Journal of Rural and Agricultural Research 19 (1) : 10-14.

Singh, K.H, Meena, K.C., Meena, B.L. and Meena, Ram Kishan. 2018. Effect of Front Line Demonstration on Sesame in Eastern Region of Rajasthan. International Journal of Microbiology Research. 10 (3): 1024-1026.

\section{How to cite this article:}

Shailesh Kumar, R. K. Tiwari, Sanjay Kumar, Ranjan Kumar, Sanchita Ghosh, Bharati Upadhaya, Nisha Rani and Vidyapati Choudhary. 2020. Performance Evaluation of Cluster Front Line Demonstration Programme on Sesame (Sesamum indicum L.) in Samastipur District, Bihar, India. Int.J.Curr.Microbiol.App.Sci. 9(05): 316-320.

doi: https://doi.org/10.20546/ijcmas.2020.905.034 